\title{
Examining Education Students' Preference for Reading Medium, Resource and Time
}

\author{
Lok Raj Sharma \\ Associate Professor of English \\ Makawanpur Multiple Campus, Hetauda, Nepal \\ E-mail:lokraj043@gmail.com
}

\begin{abstract}
The chief purpose of this research article is to examine the Bachelor of Education students' preferred reading medium, resource and time for their academic purpose. It is based on the cross sectional survey carried out at Makawanpur Multiple Campus, Nepal across the boy and girl students in 2020. The simple random sampling technique, especially lottery method was applied to select 126 students from the population of 185 students. The researcher used a questionnaire regarding the students' preference and reasons for reading medium, resource and time. The percent statistics show that $70.6 \%$ students preferred the print medium and $29.4 \%$ students preferred the print medium. The students who preferred teachers' hand-outs, text books, guide books and solution books were 42.2\%, 19.8\%, 19.0\% and $19.0 \%$ respectively. The students who preferred morning time, day time and evening time were $61.1 \%, 23.8 \%$ and $15.1 \%$ respectively. The chi-square test of independence between sex and preferred reading medium $\left[\chi^{2}(1)=2.391\right.$, critical value $=3.841$ and $\left.p(.122)>.05\right]$; between sex and preferred reading resource $\left[\chi^{2}(3)=2.595\right.$, critical value $=7.815$ and $p$ $(.458)>.05] ;$ and between sex and preferred reading time $\left[\chi^{2}(2)=.620\right.$, critical value $=$ 5.991 and $p(.733)>.05]$ show that there was no statistically significant association between sex and preferred reading medium, resource and time.
\end{abstract}

Keywords: Electronic medium, guide books, solution books, teachers' handouts, text books.

\section{Introduction}

Reading is a receptive skill. It is a scholastic phenomenon resulting in academic achievements. It is generally accepted as a way of acquiring new information and new knowledge. Academic achievements and reading are interrelated and dependent on each other. Students often come from different environments and localities with different levels of academic achievements, interests and cognitive abilities. Therefore, they differ in the patterns of reading habits and modes. 
There are diverse reading mediums and resources that students in the modern epoch can exploit for their academic purpose. With the speedy transformation of time, situation and need, diverse students are found to be reading different resources according to their circumstances and accesses. Despite diverse reading mediums and resources, the researcher selected just two broad reading mediums namely, the print medium and the electronic medium, and four common reading resources namely, text books, guide books, solution books and teachers' hand-outs to evaluate students' preferred reading medium and resource and reasons for reading. Moreover, the researcher was also interested in examining the students' preferred reading time and reasons for it.

Students' motive for reading seems to be changed. Most of the students read from their examination point of view. They have taken a short cut and easy way of learning. To succeed in the examination is more important for them than to acquire real knowledge and understanding of the text.

Makawanpur Multiple Campus, Hetauda, a leading campus in the district of Makawanpur, is situated in an urban area, but students of rural areas, urban areas, and semi-urban areas come to study here. Students from diverse geographical territories such as Hill, Valley, and Terai come here to get their higher education. Students from miscellaneous financial levels, political dogmas, religious beliefs and family backgrounds study at this campus. Therefore, it can be asserted that the students studying at this campus may represent the students of diverse campuses situated in the nation.

This research study reflects the students' strong belief in the teachers' handouts that most of them depend on the hand-outs for succeeding in the examinations. Therefore, the teachers who teach at the campus level and provide their students with their hand-outs must do justice to their students. The hand-outs must be correct, appropriate, reliable and inclusive of authentic reading materials. The teachers need to realize the significance of their hand-outs.

\section{Objectives of the study}

The key objectives of the research study are:

2.1 To evaluate the bachelor first year education students' preference for reading medium, resource and time.

2.2 To explore the reasons for the students' preference for reading medium, resource and time. 
IRJMMC Vol. 1 Issue $1 \quad$ (March, 2020) ISSN 2717-4999 (Online) 2717-4980 (Print)

2.3 To examine the association between sex and the preferred reading medium, resource and time.

\section{Null hypotheses}

The null hypotheses of the study are:

3.1 There is no statistically significant association between sex and the preferred reading medium.

3.2 There is no statistically significant association between sex and the preferred reading resource.

3.3 There is no statistically significant association between sex and the preferred reading time.

\section{Delimitations of the study}

The research study was carried out under the following delimitations:

4.1 The study included only 126 students as the respondents.

4.2 Only Bachelor first year education students were involved in the study.

4.3 The study was delimited to only one campus.

\section{Literature review}

Literature review involves concept of reading along with text books, guide books, solution books and teachers' handouts as four basic reading resources for the students' academic purpose.

\section{Concept of reading}

Reading is a receptive skill of language. It is a complex cognitive process of decoding symbols and signs for deriving meaning or constructing meaning. It is a receptive process. Everybody retains different understanding levels and can grasp or create different meanings from the same literary text. According to Rubin (2003), reading is "a process in which information from the text and the knowledge possessed by the readers act together to produce meaning" (p.3).

Reading is normally an individual activity, although a person tends to read out loud for the benefit of other listeners. Reading aloud for one's own use, for better comprehension, is a form of intrapersonal communication.

\section{Different reading resources}

The researcher used joust four types of reading resource in this study: text books, guide books, solution books and teachers' handouts. One of the most common resources in the classroom is the textbook. A textbook is a comprehensive 
compilation of content in a branch of study ("Text Book," 2020). Text books are produced to meet the needs of educators, usually at educational institutions.

A textbook is a book used for the study of a subject and asserts that People use a textbook to learn facts and methods about a certain subject ("Text Book," 2020). Textbooks sometimes have questions to test the knowledge and understanding of the learner. Most textbooks are only published in printed format. However, some are now available online as electronic books in the present time. Text books are critical inputs impacting student learning ("Text Book," 2020). Textbooks are more likely to improve student learning when they are based on a curriculum, when they employ a language that is easily understood and at an appropriate level for students and teachers, and when teachers adapt their pedagogy to achieve effective use.

A textbook Is a teaching tool (material) which presents the subject matter defined by the curriculum ("Text Book," 2020). A university textbook is required to contain the complete overview of the subject, including the theories, as well as to be of a more permanent character.

There are generally two types of text books: printed text books and digital text books. Davy (2007) found that e-textbooks had several good qualities over their traditional print copy counterparts. He found they were ubiquitous items, interactive, provided multi6 media, enabled printing on demand, thus saving paper, and could cater to individual learning styles. Woody, et al. (2010) found e-textbooks to offer greater flexibility and accessibility than print copies, and e-textbooks proved increased visual appeal. Neither of these researchers cited any disadvantages of etextbooks.

Guide books are based on sets or collections of texts. Each text collection has a shared topic or concept ("Guide Books," 2020). Guide books are supposed to be easier than the text books for students.

Solution books are these books in which solutions are given for the students so that they can get to know the answers to the questions. It is important for all the students. They can refer to these solutions while they are solving the questions from the textbook ("Solution Books," 2020).

Solution books as problem books used, usually at advanced undergraduate or post-graduate level, in which the material is organized as a series of problems, each with a complete solution given ("Solution Books," 2020). 
A handout is "a paper based resource used to support teaching and learning which can make students free from excessive note taking or supplement information not easily available elsewhere ("Hand-out," 2020). It should aid learning and may increase attention and motivation and help students to follow the development of an idea or argument.

Some researchers opine that lecture method should be combined with handouts for better teaching learning activities. Munyoro (2014) opines that lecturers should provide "additional material in the form of handouts to be read after the lecture". Race (2001) notes that, there are several advantages accompanying the use of handouts, such as making more information available to students in a few pages than they would ever be able to write down for themselves during the lecture, as well as enabling the lecturer to clarify what is to be covered in a session by providing a summary of the key ideas and concepts to be presented.

Exley and Dennick (2004) consider that handouts help students to catch up on any missed sessions and the lecturer to clarify certain information. Bligh (2000) makes an assertion that handouts are used "as sources of information was confirmed by the respondents' answers". Guevara (2014) states that a handout is a document given to students or reporters that contains information about a particular subject.

The studies carried out by Yoram- Eden and Eshet-Alkalai (2013) and Young (2014) show that speed and recall differences between media are insignificant. Rockinson-Szapkiw, Courduff, Carter and Bennett (2013), Stoop, Kreutzer and Kircz (2013b) and Sun, Chich-Jen and Kai-Ping (2013) assert that electronic documents that optimize hypertext and multimedia to engage students can lead to improved learning outcomes. Despite this, Stoop, Kreutzer and Kircz (2013a) point out that screen reading studies reveal that many students prefer to print out academic documents. Qayyum and Williamson (2014) expose that most students consider information from the printed page to be more trustworthy and find navigation and annotation functions of electronic documents inferior to paper media.

Herman (2014) and Lam, Lam and McNaught ( 2009) remark that electronic resources have grown as a cost effective alternative to print resources, with a range of multi-borrower licensing and purchase packages available within academic libraries. Rockinson-Szapkiw et al. (2013) and Stoop et al. (2013b) enunciate that electronic documents have the potential to provide an engaging, interactive learning 
environment via hyperlinks and multimedia. But Rose (2011) and Stoop et al. (2013a) find out students' preference for print versions of lengthy academic texts. Daniel and Woody (2013) also discern students' preference for print books over electronic, despite minimal differences in their post-test quiz results.

Tuncer and Bahadir (2014) and Martin and Platt (2001) in their studies ascertain that that participants preferred to print out documents that contained complex information for reading. Jabr (2013) asserts it can be difficult to ascertain how far one is through a multi-page article, while also contextualizing the passages within the document while reading from the screen media. Lam et al. (2009) mention that e-book publishers are increasingly offering readers more visual functions to ease the electronic reading process. These include page turning visualizations, text scrolling and searching functions, links to multi-media, and visual cues that show the reader how many pages into the document they are. Peek (2005) finds out a significant increase in e-book production and sale. Dyson and Haselgrove (2000) assume that Computers play an active role in distance education, further increasing the rate of use of electronic texts. Rose (2011) views that electronic texts have superseded traditional printed paper, electronic texts have superseded traditional printed paper. Mills and Weldon (1987) and Dillon (1992) find out in the studies the shift from printed text to electronic texts due to the widespread use of personal computers in the 1980s. Kropman, Schoch and Yeoh (2004) and Young (2000) clarify that computer use is tiresome compared to reading a book, and computer displays cause eye fatigue. Therefore, the use of electronic texts remains low in comparison with printed texts. Woody, Daniel and Baker (2010) state readers continue to experience physical problems and decreased performance when reading electronic texts, and they prefer printed texts. Dockrell, Earle and Galvin (2010), Levine-Clark (2006), McGrail (2007) and Woody, Daniel and Baker (2010) discover that readers prefer printed texts due to ergonomic challenges in computer use. Blanco and Leirøs (2000), Garland and Noyes (2004), Kropman, Schoch and Yeoh (2004), Nishiyama (1990), Rose (2011), Wu, Lee and Lin (2007) and Young (2000) find out that students prefer the printed media to the electronic media that cause eyestrain. Woody, Daniel and Baker (2010) suggest that developments in technology must attempt to overcome the disadvantages of e-books. 
Literature reviews mentioned above tell us that students have different preferences for their reading mediums and resources. No medium or no resource is without any demerits.

\section{Methodology}

Methodology involves research design, population, sampling design, sample size, variables, nature, validity of instrument, nature and sources of data and analysis and interpretation of data. A cross-sectional survey design was used to carry out the study. The researcher collected the primary data from the questionnaire to investigate the Bachelor of Education students' preference for preferred reading medium, resource and time. The population of the study consisted of 185 Bachelor of education students studying at Makawanpur Multiple Campus, Nepal in the Academic Year 2020. The researcher followed the simple random sampling design, especially the lottery method to select 126 students from the campus according to the sample size determination calculator by maintaining $95 \%$ confidence level and $5 \%$ margin of error.

Sample size by sex

The sample size of the research study consisted of 36 boys and 90 girls studying at the campus.

\section{Percent of Students by Sex}

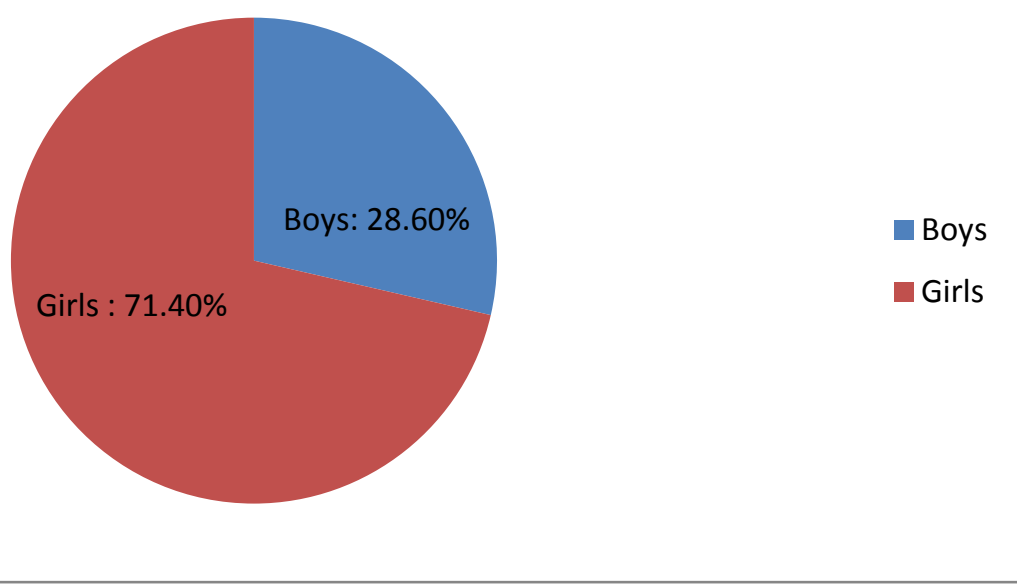

Figure 1: Percent of students by sex

This figure shows that the percent of boys was a noticeably smaller than that of the girls.

Religions of the students

103 students belonged to Hinduism, 16 students belonged to Buddhism and 7 students belonged to Christianity. 


\section{Percent of Students by Religion}

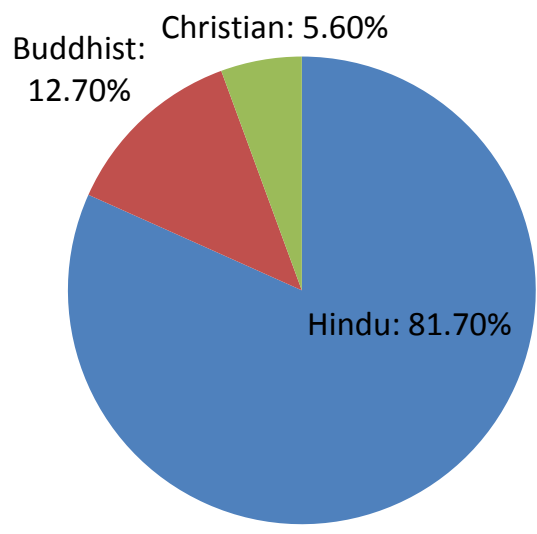

- Hindu

Buddhist

Christian

Figure 2: Percent of students belonging to different religions in the study

This figure shows that highest number of the students in the study belonged to Hinduism.

Ethnic groups of the students

35 Brahman, 11 Kshetri, 27 Janajati, 10 Madhesi, 5 Dalit and 38 Educationally

Disadvantaged Janajati (EDJ) students formed the sample size of the study.

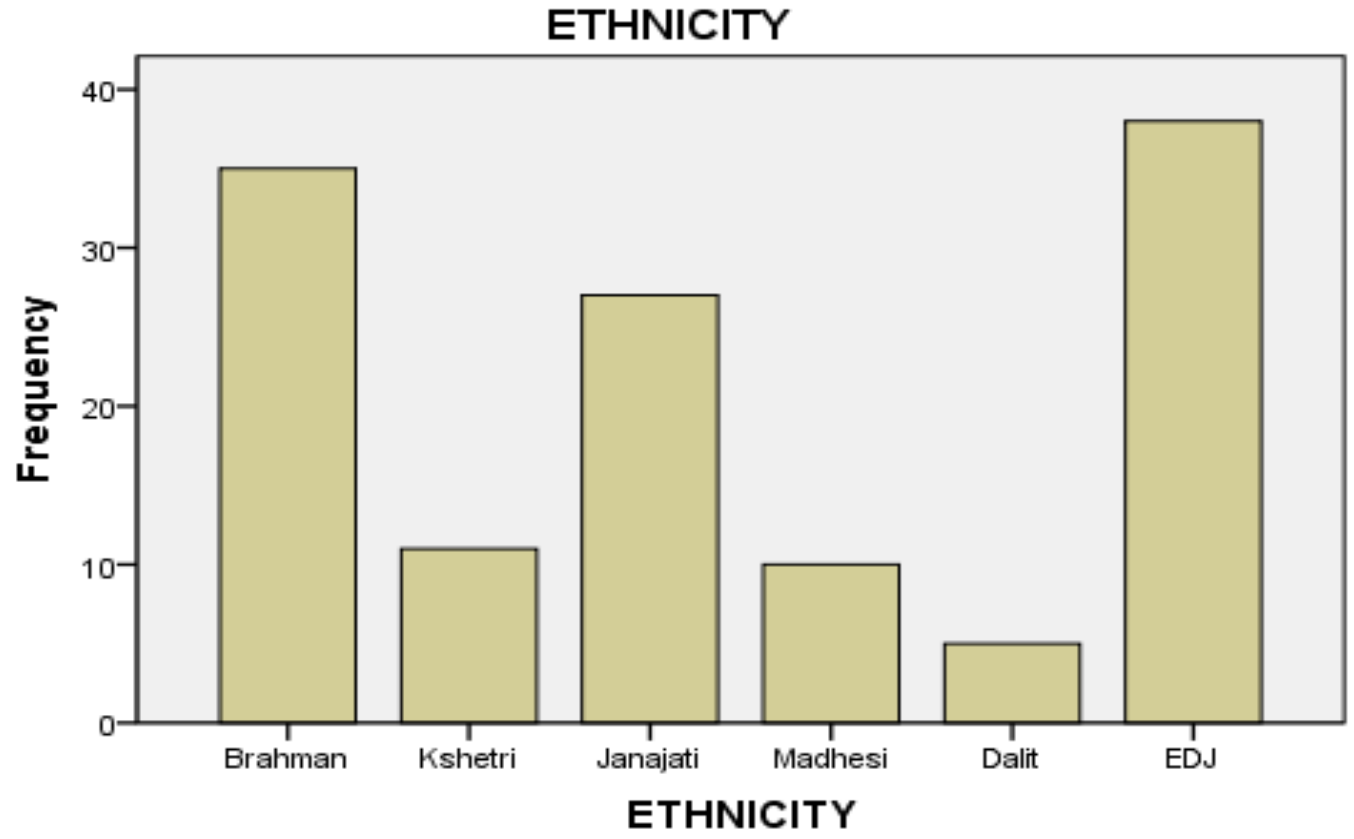

Figure 3: Number of students belonging to different religions in the study 


\section{Variables in the Study}

In this cross-sectional survey research design, the researcher took Sex, Preferred reading resource, Semester and reasons for preference of particular resource as major variables.

Validity of the instruments

Validity refers to the state of being valid, authentic or genuine. To measure the validity of the instruments, the researcher received opinions and judgments from subject experts and teachers.

\section{Nature and source of data}

The researcher exploited nominal data to carry out the research study. Students' preference for reading medium, resource and time were obtained through the use of objective. The primary source of data was questionnaire. The secondary source of data included books, journal articles, web-sites reading materials etc.

\section{Analysis and interpretation of data}

All the data were analyzed by using Statistical Package for Social Sciences (SPSS) 20 version. The researcher designed a series of question items to elicit the categorical data. Being the data nominal or categorical, the researcher used the frequency and percent statistics to evaluate which reading medium, resource and time is preferred by more students. The chi-square test of independence was employed to assess the hypothesis test or to determine the association between sex and the preferred reading medium, resource and time.

\section{Students' preference for the reading medium}

The researcher used frequency and percent calculation to examine the students' preference for the reading medium.

Table 1: Students' preference for the reading medium

\begin{tabular}{lrrrr}
\hline Medium & Frequency & \multicolumn{1}{l}{ Percent } & Valid Percent & $\begin{array}{c}\text { Cumulative } \\
\text { Percent }\end{array}$ \\
\hline Print & 89 & 70.6 & 70.6 & 70.6 \\
Electronic & 37 & 29.4 & 29.4 & 100.0 \\
Total & 126 & 100.0 & 100.0 & \\
\hline
\end{tabular}

This table shows that most of the students preferred the print medium. 
Table 2: Reasons for preferring the print and electronic medium

\begin{tabular}{|c|c|c|c|c|c|}
\hline Medium & Reasons & Frequency & Percent & $\begin{array}{c}\text { Valid } \\
\text { Percent }\end{array}$ & $\begin{array}{c}\text { Cumulative } \\
\text { Percent }\end{array}$ \\
\hline & $\begin{array}{l}\text { Easy to underline } \\
\text { main points }\end{array}$ & 33 & 26.2 & 26.2 & 26.2 \\
\hline \multirow[t]{4}{*}{ Print } & $\begin{array}{l}\text { Do not cause eye } \\
\text { strain. }\end{array}$ & 35 & 27.8 & 27.8 & 54.0 \\
\hline & $\begin{array}{l}\text { Less distraction in the } \\
\text { course of reading. }\end{array}$ & 21 & 16.7 & 16.7 & 70.6 \\
\hline & Interesting to read. & 29 & 23.0 & 23.0 & 93.7 \\
\hline & Easy to read & 2 & 1.6 & 1.6 & 95.2 \\
\hline \multirow[t]{3}{*}{ Electronic } & $\begin{array}{l}\text { Easy to copy the main } \\
\text { points for writhing. }\end{array}$ & 2 & 1.6 & 1.6 & 96.8 \\
\hline & $\begin{array}{l}\text { No need to buy } \\
\text { separate books }\end{array}$ & 4 & 3.2 & 3.2 & 100.0 \\
\hline & Total & 126 & 100.0 & 100.0 & \\
\hline
\end{tabular}

This table demonstrates that most of the students who preferred the print medium considered that it did not cause eye strain. Most of the students who preferred the electronic medium assumed it to have been interesting to read.

Students' preference for the reading resources

Text Books, Guide Books, Solution Books and Teachers' Hand-outs were taken as reading resources for examining the students' preference.

Table 3: Students' preference for the reading resources

\begin{tabular}{lrrrr}
\hline Resources & Frequency & Percent & \multicolumn{1}{c}{$\begin{array}{c}\text { Valid } \\
\text { Percent }\end{array}$} & $\begin{array}{c}\text { Cumulative } \\
\text { Percent }\end{array}$ \\
\hline Text Books & & & \multicolumn{1}{c}{19.8} \\
Guide Books & 25 & 19.8 & 19.8 & 38.9 \\
Solution Books & 24 & 19.0 & 19.0 & 57.9 \\
Teachers' Hand-outs & 24 & 19.0 & 19.0 & 100.0 \\
Total & 53 & 42.2 & 42.1 & \\
\hline
\end{tabular}

This table exhibits that most of the students preferred the teachers' hand-outs for their academic purpose. 
Reasons for Students' Preference for the Reading Resources

The researcher was interested to assess why the students preferred particular types of reading resources.

Table 4: Reasons for students' preference for the reading resources

\begin{tabular}{|c|c|c|c|c|c|}
\hline Resource & Reasons & Frequency & Percent & $\begin{array}{c}\text { Valid } \\
\text { Percent }\end{array}$ & $\begin{array}{c}\text { Cumulative } \\
\text { Percent }\end{array}$ \\
\hline \multirow[t]{3}{*}{ Text Books } & $\begin{array}{l}\text { Retain detailed } \\
\text { sources of } \\
\text { information }\end{array}$ & 24 & 19.0 & 19.0 & 19.0 \\
\hline & $\begin{array}{l}\text { Provide us with } \\
\text { authentic reading } \\
\text { materials. }\end{array}$ & 1 & .8 & .8 & 19.8 \\
\hline & $\begin{array}{l}\text { Useful for the } \\
\text { examinations }\end{array}$ & 13 & 10.3 & 10.3 & 30.2 \\
\hline \multirow[t]{4}{*}{ Guide Books } & Easy to remember & 2 & 1.6 & 1.6 & 31.7 \\
\hline & $\begin{array}{l}\text { Helpful in preparing } \\
\text { the notes for the } \\
\text { examinations }\end{array}$ & 1 & .8 & .8 & 32.5 \\
\hline & $\begin{array}{l}\text { Provide us with } \\
\text { required information. }\end{array}$ & 8 & 6.3 & 6.3 & 38.9 \\
\hline & $\begin{array}{l}\text { Useful for the } \\
\text { examinations }\end{array}$ & 14 & 11.1 & 11.1 & 50.0 \\
\hline \multirow[t]{3}{*}{ Books } & Easy to remember & 8 & 6.3 & 6.3 & 56.3 \\
\hline & $\begin{array}{l}\text { Give us ideas how to } \\
\text { answer the questions } \\
\text { in the examinations. }\end{array}$ & 2 & 1.6 & 1.6 & 57.9 \\
\hline & $\begin{array}{l}\text { Useful for the } \\
\text { examinations }\end{array}$ & 41 & 32.5 & 32.5 & 90.5 \\
\hline \multirow[t]{3}{*}{ Hand-outs } & $\begin{array}{l}\text { Reliable resources to } \\
\text { study }\end{array}$ & 10 & 7.9 & 7.9 & 98.4 \\
\hline & $\begin{array}{l}\text { Short and easy to } \\
\text { read and remember }\end{array}$ & 2 & 1.6 & 1.6 & 100.0 \\
\hline & Total & 126 & 100.0 & 100.0 & \\
\hline
\end{tabular}

This table reveals that most of the students who preferred the Text Books considered that they retained detailed sources of information. Most of the students who liked the Guide Books thought that they were useful for the examinations. Most of students who preferred the Solution Books assumed that they were useful for their 
examinations. 32.5 percent students preferred the Teachers' Hand-outs for their examinations. This clearly shows that most of the students' prime focus was to pass the examinations, but not to gain sound and detailed knowledge.

\section{Students' preference for the reading time}

The campus runs its classes in morning, day and evening shifts. The bachelor education classes are run in the morning shift.

Table 5: Students' preference for the reading time

\begin{tabular}{lcccr}
\hline $\begin{array}{l}\text { Preferred Reading } \\
\text { Time }\end{array}$ & Frequency & Percent & Valid Percent & \multicolumn{1}{c}{$\begin{array}{c}\text { Cumulative } \\
\text { Percent }\end{array}$} \\
\hline Morning & 77 & 61.1 & 61.1 & 61.1 \\
Day & 30 & 23.8 & 23.8 & 84.9 \\
Night & 19 & 15.1 & 15.1 & 100.0 \\
Total & 126 & 100.0 & 100.0 & \\
\hline
\end{tabular}

This table indicates that most of the students were satisfied with the classes running in the morning shift

Table 6: Reasons for students' preference for the reading time

\begin{tabular}{|c|c|c|c|c|c|}
\hline $\begin{array}{l}\text { Preferred } \\
\text { Reading Time }\end{array}$ & Reasons & Frequency & Percent & $\begin{array}{l}\text { Valid } \\
\text { Percent }\end{array}$ & $\begin{array}{l}\text { Cumulative } \\
\text { Percent }\end{array}$ \\
\hline \multirow{4}{*}{ Morning } & $\begin{array}{l}\text { It is refreshing and } \\
\text { peaceful }\end{array}$ & 35 & 27.8 & 27.8 & 27.8 \\
\hline & $\begin{array}{l}\text { I can remember well } \\
\text { what I read }\end{array}$ & 41 & 32.5 & 32.5 & 60.3 \\
\hline & $\begin{array}{l}\text { I can remember well } \\
\text { what I am taught. }\end{array}$ & 1 & .8 & .8 & 61.1 \\
\hline & $\begin{array}{l}\text { I can remember well } \\
\text { what I read. }\end{array}$ & 2 & 1.6 & 1.6 & 62.7 \\
\hline Day & $\begin{array}{l}\text { I am with my friends } \\
\text { and prefer to read } \\
\text { with them }\end{array}$ & 28 & 22.2 & 22.2 & 84.9 \\
\hline \multirow{4}{*}{ Evening } & $\begin{array}{l}\text { It is refreshing and } \\
\text { peaceful. }\end{array}$ & 1 & .8 & .8 & 85.7 \\
\hline & $\begin{array}{l}\text { I can remember well } \\
\text { what I read. }\end{array}$ & 2 & 1.6 & 1.6 & 87.3 \\
\hline & $\begin{array}{l}\text { I become alone and } \\
\text { read well in this time }\end{array}$ & 16 & 12.7 & 12.7 & 100.0 \\
\hline & Total & 126 & 100.0 & 100.0 & \\
\hline
\end{tabular}

This table shows that most of the students preferred the morning time because they could remember well what they read. Students preferred the day time because they 
preferred to study with their friends in the group, whereas some preferred the evening time because they were alone and read well in this period.

Table 7: Association between sex and the preferred reading medium

\begin{tabular}{|c|c|c|c|c|c|}
\hline & & & \multicolumn{2}{|c|}{ Preferred Medium } & \multirow{3}{*}{ Total } \\
\hline & & & Print & Electronic & \\
\hline & & & Medium & Medium & \\
\hline & Boys & Count & 29 & 7 & 36 \\
\hline & & $\%$ Within Sex & $80.6 \%$ & $19.4 \%$ & $100.0 \%$ \\
\hline & & $\%$ Within Preferred & $32.6 \%$ & $18.9 \%$ & $28.6 \%$ \\
\hline \multirow[t]{8}{*}{ Sex } & & Medium & & & \\
\hline & & $\%$ Of Total & $23.0 \%$ & $5.6 \%$ & $28.6 \%$ \\
\hline & Girls & Count & 60 & 30 & 90 \\
\hline & & $\%$ Within Sex & $66.7 \%$ & $33.3 \%$ & $100.0 \%$ \\
\hline & & $\%$ Within Preferred & $67.4 \%$ & $81.1 \%$ & $71.4 \%$ \\
\hline & & Medium & & & \\
\hline & & $\%$ Of Total & $47.6 \%$ & $23.8 \%$ & $71.4 \%$ \\
\hline & & Count & 89 & 37 & 126 \\
\hline \multirow[t]{4}{*}{ Total } & & $\%$ Within Sex & $70.6 \%$ & $29.4 \%$ & $100.0 \%$ \\
\hline & & $\%$ Within Preferred & $100.0 \%$ & $100.0 \%$ & $100.0 \%$ \\
\hline & & Medium & & & \\
\hline & & $\%$ Of Total & $70.6 \%$ & $29.4 \%$ & $100.0 \%$ \\
\hline
\end{tabular}

This table shows that both boys and girls preferred the print medium more than the electronic medium of reading.

\section{Chi-Square test of independence}

Chi-square test of independence was computed to examine the association between sex and the preferred reading medium.

Table 8: Chi-Square test of independence (Sex and preferred reading medium)

\begin{tabular}{lccc}
\hline & Value & $\mathrm{df}$ & \multicolumn{2}{c}{ Asymp. Sig. (2-sided) } \\
\hline Pearson Chi-Square & $2.391^{\mathrm{a}}$ & 1 & .122 \\
Likelihood Ratio & 2.518 & 1 & .113 \\
Linear-by-Linear Association & 2.372 & 1 & .123 \\
N of Valid Cases & 126 & & \\
\hline
\end{tabular}

a. 0 cells $(0.0 \%)$ have expected count less than 5 . The minimum expected count is 10.57 .

b. Computed only for a $2 \times 2$ table 
"Pearson Chi-Square" value $\chi 2(1)=2.391$, which is smaller than the critical value 3.841 and $p=.122$, which was greater than .05 . This tells us that there was no statistically significant association between sex and preferred reading medium. It means both male students and female students almost equally preferred the print medium. The result of the Chi-Square test of independence accepted the null hypothesis that there was no statistically significant association between sex and the preferred reading medium in the study.

Table 9: Association between sex and the preferred reading resources

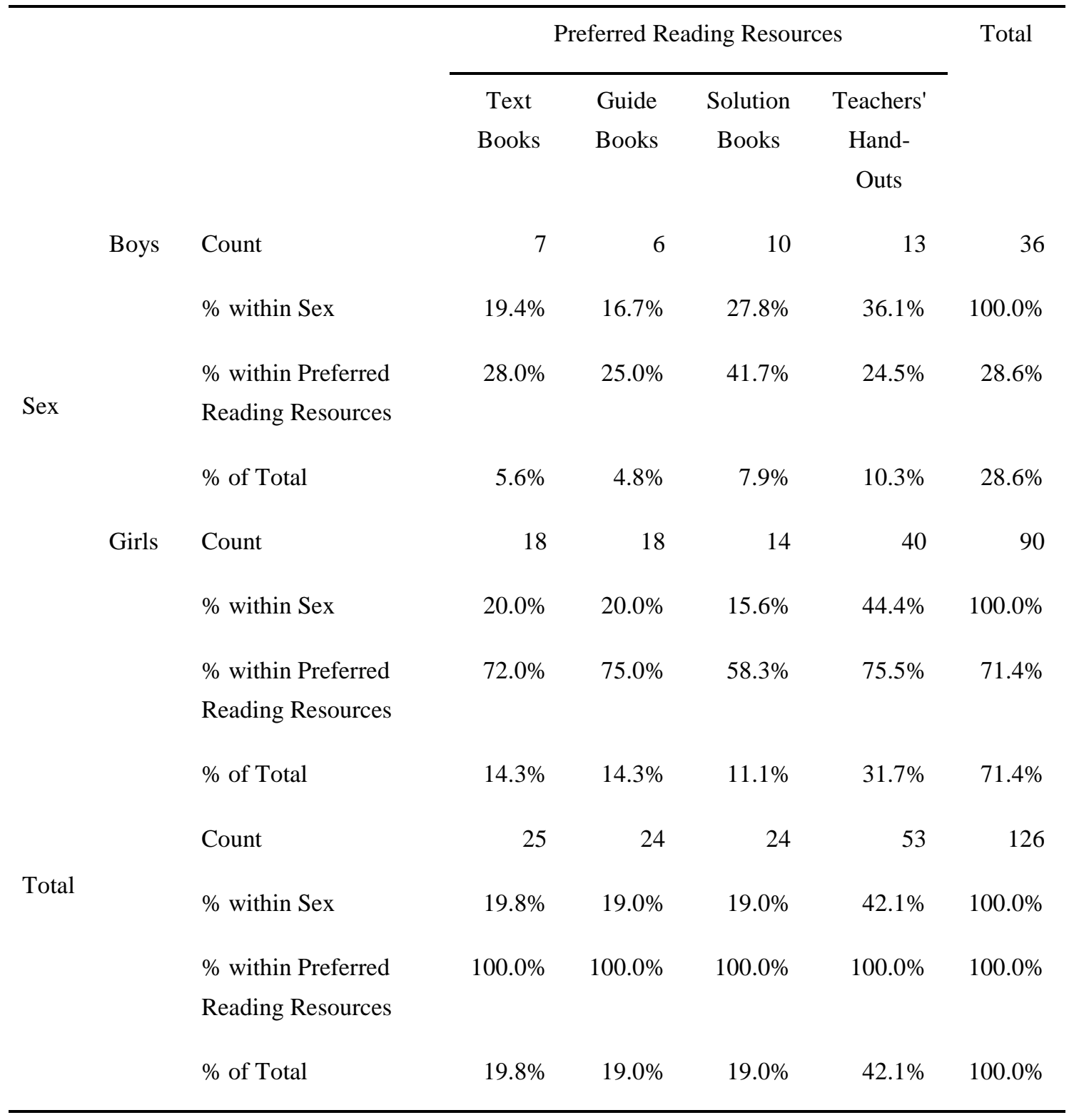

This table shows that both boys and girls preferred the teachers' hand-outs more than other reading resources. 
Table 10: Chi-square test of independence (Sex and preferred reading resources)

\begin{tabular}{|c|c|c|c|}
\hline & Value & $\mathrm{df}$ & Asymp. Sig. (2-sided) \\
\hline Pearson Chi-Square & $2.595^{\mathrm{a}}$ & 3 & .458 \\
\hline Likelihood Ratio & 2.471 & 3 & 481 \\
\hline Linear-by-Linear Association & .028 & 1 & .867 \\
\hline $\mathrm{N}$ of Valid Cases & 126 & & \\
\hline
\end{tabular}

a. 0 cells $(0.0 \%)$ have expected count less than 5 . The minimum expected count is 8.86 .

b. Computed only for a $2 \times 2$ table

"Pearson Chi-Square" value $\chi^{2}(3)=2.595$, which is smaller than the critical value 7.815 and $p=.458$, which was greater than .05 . This tells us that there was no statistically significant association between sex and preferred reading resource. It means both male students and female students almost equally preferred the teachers' hand-outs. The result of the Chi-Square test of independence accepted the null hypothesis that there was no statistically significant association between sex and the preferred reading resource in the study.

Table 11: Association between sex and the preferred reading time

\begin{tabular}{|c|c|c|c|c|c|c|}
\hline & & & \multicolumn{3}{|c|}{ Preferred Reading Time } & \multirow[t]{2}{*}{ Total } \\
\hline & & & Morning & Day & Evening & \\
\hline & Boys & Count & 23 & 9 & 4 & 36 \\
\hline & & $\%$ within Sex & $63.9 \%$ & $25.0 \%$ & $11.1 \%$ & $100.0 \%$ \\
\hline & & $\%$ within Preferred & $29.9 \%$ & $30.0 \%$ & $21.1 \%$ & $28.6 \%$ \\
\hline \multirow[t]{8}{*}{ Sex } & & Reading Time & & & & \\
\hline & & $\%$ of Total & $18.3 \%$ & $7.1 \%$ & $3.2 \%$ & $28.6 \%$ \\
\hline & Girls & Count & 54 & 21 & 15 & 90 \\
\hline & & $\%$ within Sex & $60.0 \%$ & $23.3 \%$ & $16.7 \%$ & $100.0 \%$ \\
\hline & & $\%$ within Preferred & $70.1 \%$ & $70.0 \%$ & $78.9 \%$ & $71.4 \%$ \\
\hline & & Reading Time & & & & \\
\hline & & $\%$ of Total & $42.9 \%$ & $16.7 \%$ & $11.9 \%$ & $71.4 \%$ \\
\hline & & Count & 77 & 30 & 19 & 126 \\
\hline \multirow[t]{4}{*}{ Total } & & $\%$ within Sex & $61.1 \%$ & $23.8 \%$ & $15.1 \%$ & $100.0 \%$ \\
\hline & & $\%$ within Preferred & $100.0 \%$ & 100.0 & $100.0 \%$ & $100.0 \%$ \\
\hline & & Reading Time & & $\%$ & & \\
\hline & & $\%$ of Total & $61.1 \%$ & $23.8 \%$ & $15.1 \%$ & $100.0 \%$ \\
\hline
\end{tabular}

This table shows that both boys and girls preferred the morning time more than other time. 
Table 12: Chi-Square test of independence (Sex and preferred reading time)

\begin{tabular}{lccc}
\hline & Value & df & \multicolumn{2}{c}{ Asymp. Sig. (2-sided) } \\
\hline Pearson Chi-Square & $.620^{\mathrm{a}}$ & 2 & .733 \\
Likelihood Ratio & .652 & 2 & .722 \\
Linear-by-Linear Association & .414 & 1 & .520 \\
N of Valid Cases & 126 & & \\
\hline
\end{tabular}

a. 0 cells $(0.0 \%)$ have expected count less than 5 . The minimum expected count is 5.43 .

"Pearson Chi-Square" value $\chi^{2}(2)=.620$, which is smaller than the critical value 5.991 and $p=.733$, which was greater than .05 . This tells us that there was no statistically significant association between sex and preferred reading time. It means both male students and female students almost equally preferred morning time. The result of the Chi-Square test of independence accepted the null hypothesis that there was no statistically significant association between sex and the preferred reading time in the study.

\section{Conclusion}

Frequency and percent statistics show that 89 or $70.6 \%$ ), students preferred the print medium and 37 or $29.4 \%$ students preferred the electronic medium. 25 or $19.8 \%$ percent students preferred the text books, 24 or $19.0 \%$ students preferred the guide books, 24 or $19.0 \%$ students preferred the solution books , and the most of the students (53or $42.2 \%$ ) prefered the teachers' hand-outs. Similarly, 77 or $61.1 \%$ students preferred the morning time, 30 or $23.8 \%$ students preferred day time and 19 or $15.1 \%$ preferred the evening time. The results indicate that the majority of students preferred the print medium for not causing the eye strain, the teachers' hand-outs more than other reading resources for being useful for the examinations, and the morning time for making them remember well what they read.

"Pearson Chi-Square" value between sex and the preferred reading medium $\chi^{2}$ $(1)=2.391$, which is smaller than the critical value 3.841 and $p=.122$, which was greater than .05 show us that there was no statistically significant association between sex and preferred reading medium. Similarly, the chi-square test of independence between sex and the preferred reading resource $\chi^{2}(3)=2.595$, which is smaller than the critical value 7.815 and $p=.458$, which was greater than .05 demonstrate that 
there was no statistically significant association between sex and the preferred reading resource. Finally, the chi-square test of independence between sex and the preferred reading time $\chi^{2}(2)=.620$, which is smaller than the critical value 5.991 and $p=.733$, which was greater than .05 reveal that there was no statistically significant association between sex and the preferred reading time.

Varied modes and models are adopted in the fields of teaching learning activities in the modern era. Students' preferences for reading medium, resource and time can be found diversified according to their levels, backgrounds, locales, financial conditions and attitudes towards and learning destination. Learning surroundings, physical facilities and subject teachers can also determine the students' preference for reading medium and resource. Despite the diversity of students and the possibility of various reading mediums and resources, this study shows that most of the Nepalese students prefer the print reading medium and the teachers' hand-outs for their academic purposes. They prefer to read in the morning. This research article is significant in the field of teaching-learning activities that involve the students' preference for diverse reading medium, resources and time, and reasons for their preference.

\section{Acknowledgements}

I am thankful to Dr. Shankar Prasad Upadhyaya, Campus Chief, Makawanpur Multiple Campus, Hetauda, Dr. Ram Prasad Adhikari, Mr. Rameshwor Baral and Dr. Yam Bahadur Silwal, Assistant Campus Chiefs, for their persistent encouragement and support in the field of research and writing journal articles. I am also thankful to the education first year students of Makawanpur Multiple Campus, Hetauda, for their sincere responses of the questionnaire.

\section{References}

Blanco, M. J. \& Leirøs, L. I. (2000). Temporal variation in the luminance level of stimuli displayed on a cathode-ray tube monitor: Effects on performance on a visual vigilance task. Ergonomics, 43, 239- 251.

Bligh, D. A. (2000). What's the use of lectures? London: Jossey-Bass: A Wiley Company: Higher and Adult Education Series.

Daniel, D., \& Woody, W. D. (2013). E-textbooks at what cost? Performance and use of electronic v. print texts. Computers \& Education, 62, 18-23. doi:10.1016/j.compedu.2012.10.1016 
Davy, T. (2007). E-textbooks: Opportunities, innovations, distractions, and dilemmas. Serials, 20(2), 98-102.

Dillon, A. (1992). Reading from paper versus screens: a critical review of the empirical. Ergonomics, 35(10), 1297-1326.

Dockrell, S., Earle, D., \& Galvin, R. (2010). Computer-related posture and discomfort in primary school children: The effects of a school-based ergonomic intervention. Computers \& Education, 55(1), 276- 284.

Durant, D. M., \& Horava, T. (2015). The future of reading and academic libraries. Portal: Libraries and the Academy, 15, 5-27. Retrieved from https://musejhu.edu.ezproxy.lib.rmit.edu.au/journals/ portal_libraries_and_the_academy/v015/15.1.durant.html

Dyson, M. C., \& Haselgrove, M. (2001). The influence of reading speed and line length on the effectiveness of reading from screen. Int. J. Human-Computer Studies, 54, 585-612.

Exley, K. \& Dennick, R. (2004) Giving a lecture from presenting to teaching: Key guides for effective teaching in higher education: London: Routledge Falmer: Taylor and Francis Group.

Guide book. (2020, February 24). Retrieved from http://www.louisianabelieves.com/docs/default-source/teacher-toolboxresources/ela-guidebooks-2-0-feedback-report.pdf?sfvrsn=2.

Herman, P. (2014, September 29). The hidden costs of e-books as university libraries. Times of San Diego. Retrieved from http://timesofsandiego.com/opinion/2014/09/29/hidden-costs-e books university- libraries/

Jabr, F. (2013). The reading brain in the digital age: The science of paper versus screens. Scientific American, Retrieved from www.scientificamerican.com/article/reading-paper-screens/

Kropman, M., Schoch, H. P., \& Yeoh, H. Y. (2004). An experience in e-learning: Using an electronic textbook. In R. Atkinson, C. McBeath, D. Jonas-Dwyer, \& R.

Lam, P., Lam, S., \& McNaught, C. (2009). Usability and usefulness of eBooks on PPCs: How students' opinions vary over time. Australasian Journal of Educational Technology, 25, 30-44. Retrieved from Proquest. 
Levine-Clark, M. (2006). Electronic book usage: A survey at the University of Denver. Libraries and the Academy, 6(3), 285-299.

Martin, L., \& Platt, M. (2001). Printing and screen reading in the medical school curriculum: Guttenberg vs. the cathode ray tube. Behaviour \& Information Technology, 20, 143-148. doi:10.1080/01449290110048043

Mills, C. B., \& Weldon, L. J. (1987). Reading text from computer screens. ACM Computing Surveys, 19(4), 329-357.

Munyoro, G. (2014). An evaluation of the effectiveness of handouts in enhancing teaching and learning in higher education. ADRRI JOURNAL. 5(2), 1-19, Nishiyama, K. (1990). Ergonomic aspect of the health and safety of VDT work in Japan: a review. Ergonomics, 33, 659-685.

Peek, R. (2005). The e-books redux. Information Today, 22(7), 17-18. Phillips (Eds.) (2015). Beyond the comfort zone: Proceedings of the 21 st ASCILITE conference (512-515). Perth: Western Australia, 5-8 December.

Retrieved from.

http://www.ascilite.org.au/conferences/perth04/procs/Kropman.html.

Problem book. (2020, February 24). Retrieved from https://en.wikipedia.org/wiki/Problem_book.

Qayyum, A., \& Williamson, K. (2014). The online information experiences of newsseeking young adults. Information Research, 20(2). Retrieved from http://www.informationr.net/ir/19-2/paper615. html\#.V2p9oaJXJh4

Race, P. (2001) Lecturer's toolkit: Learning, teaching and assessment. London: Kogan Page Limited.

Rockinson-Szapkiw, A., Courduff, J., Carter, K., \& Bennett, D. (2013). Electronic versus traditional print textbooks: A comparison study on the influence of university students' learning. Computers and Education, 63, 259-266. doi:10/1016/j.compedu.2012.11.022

Rubin, D. (2003). K.U.A.S.A.I. Lebih cepat: Buku pintar accelerated learning. Translated by F. Syahrani. Bandung: Kaifa.

Solution book. (2020, February 24). Retrieved from https://schools.aglasem.com/ncert/ncert-solutions-class-6-hindi/amp/. .

Stoop J., Kreutzer, P., \& Kircz, J. (2013). Reading and learning from screen versus print: A study in changing habits; Part 1. New Library World, 114, 284-300. doi:10.1108/NLW-01-2013-0012 
Sun, S. Y., Chich-Jen, S., \& Kai-Ping, H. (2013). A research on comprehension differences between print and screen reading. South African Journal of Economic and Management Sciences, 16, 87-101. Retrieved from http://www.sajems.org/index.php/sajems/article/view/640

Teaching handouts. (2020, February 24). Retrieved from http://www.wmin.ac.uk/mcshand/TEACHING/handouts.htm.

Text book. (2020, February 22). Retrieved from https://en.wikipedia.org/wiki/Textbook.

Text book. (2020, February 22). Retrieved from https://simple.wikipedia.org/wiki/Textbook.

Text book and teachers'guides. (2020, February 23). Retrieved from https://learningportal.iiep.unesco.org/en/issue-briefs/improvelearning/curriculum-and-materials/textbooks-and-teachers-guides-availability.

Tuncer, M., \& Bahadir, F. (2014). Effect of screen reading and reading from printed out material on student success and permanency in introduction to computer lesson. Turkish Online Journal of Educational Technology, 13, 44-49. Retrieved from http://www.tojet.net/articles/v13i3/1335.pdf

Woody, W. D., Daniel, D. B., \& Baker, C. A. (2010). E-books or textbooks: Students prefer textbooks. Computers \& Education, 55, 945-948.

Wu, H. C., Lee, C. L., \& Lin, C. T. (2007). Ergonomic evaluation of three popular Chinese e-book displays for prolonged reading. International Journal of Industrial Ergonomics, 37, 761-770.

Yoram- Eden, S., \& Eshet-Alkalai, Y. (2013). The effect of format on performance: Editing text in print versus digital formats. British Journal of Educational Technology, 44, 846-856. doi:10.1111/j.1467- 8535.2012.01332.x

Young, B. J. (2000). Gender differences in student attitudes toward computers. Journal of Research on Computing in Education, 33, 204-216.

Young, B. J. (2014). A study of print and computer-based reading to measure and compare rates of comprehension and retention. New Library World, 115, 376393. doi:10.1108/NLW-05-2014-0051 